Article

\title{
Synergistic Interaction of Climate and Land-Use Drivers Alter the Function of North American, Prairie-Pothole Wetlands
}

\author{
Owen P. McKenna ${ }^{1}$ * ${ }^{\mathbb{D}}$, Samuel R. Kucia ${ }^{1}$, David M. Mushet ${ }^{1}$, Michael J. Anteau ${ }^{1}$ and \\ Mark T. Wiltermuth ${ }^{2}$ \\ 1 U.S. Geological Survey, Northern Prairie Wildlife Research Center, Jamestown, ND 58401, USA; \\ skucia@contractor.usgs.gov (S.R.K.); dmushet@usgs.gov (D.M.M.); manteau@usgs.gov (M.J.A.) \\ 2 U.S. Geological Survey, Upper Midwest Environmental Sciences Center, La Crosse, WI 54603, USA; \\ mwiltermuth@usgs.gov \\ * Correspondence: omckenna@usgs.gov; Tel.: 1-701-253-5527
}

Received: 30 September 2019; Accepted: 19 November 2019; Published: 21 November 2019

\begin{abstract}
Prairie-pothole wetlands provide the critical habitat necessary for supporting North American migratory waterfowl populations. However, climate and land-use change threaten the sustainability of these wetland ecosystems. Very few experiments and analyses have been designed to investigate the relative impacts of climate and land-use change drivers, as well as the antagonistic or synergistic interactions among these drivers on ecosystem processes. Prairie-pothole wetland water budgets are highly dependent on atmospheric inputs and especially surface runoff, which makes them especially susceptible to changes in climate and land use. Here, we present the history of prairie-pothole climate and land-use change research and address the following research questions: 1) What are the relative effects of climate and land-use change on the sustainability of prairie-pothole wetlands? and 2) Do the effects of climate and land-use change interact differently under different climatic conditions? To address these research questions, we modeled 25 wetland basins (1949-2018) and measured the response of the lowest wetland in the watershed to wetland drainage and climate variability. We found that during an extremely wet period (1993-2000) wetland drainage decreased the time at which the lowest wetland reached its spill point by four years, resulting in 10 times the amount of water spilling out of the watershed towards local stream networks. By quantifying the relative effects of both climate and land-use drivers on wetland ecosystems our findings can help managers cope with uncertainties about flooding risks and provide insight into how to manage wetlands to restore functionality.
\end{abstract}

Keywords: prairie pothole wetlands; climate change; land-use change; wetland drainage; PHyLiSS model

\section{Introduction}

Climate and land-use change are two major drivers that threaten the sustainability of non-floodplain wetlands known collectively as "vulnerable waters" [1]. Very few experiments and analyses are designed to investigate the relative impacts of multiple global-change drivers as well as the antagonistic or synergistic interactions among drivers on ecosystem processes [2]. In the absence of manipulative experiments aimed at addressing the relative impacts and interactions between climate and land-use change on ecosystem processes, a priori approaches are used to analyze existing data and explore the gross effects of change [3]. There is a current need to design studies identifying the relative impact of climate and land-use change on different physical (e.g., hydroperiod and salinity) 
and biological (e.g., vegetation and aquatic macroinvertebrate communities) variables of interest in areas where vulnerable wetlands that have been well documented as a "disappearing ecosystem" [4].

The Prairie Pothole Region (PPR) covers approximately $777,000 \mathrm{~km}^{2}$ of the North American midcontinent (Figure 1). Over half of the historical wetlands in the PPR have been drained, and conversion of upland areas to crops has altered wetland functioning and the ecosystem services provided by wetlands [5]. Millions of small, glacially derived wetlands that provide critical habitat for migratory waterfowl [5] and other wetland-dependent species [6,7] occur in the PPR, making it a continentally significant region for biodiversity [8]. The wetlands of the PPR also provide additional ecosystem services such as floodwater storage, sediment reduction, water-quality improvement [9], and carbon sequestration [10]. The need to tease apart the complexity caused by interactions between climate and land-use change drivers and how they affect biodiversity, in general, has been recently established as a pressing research priority for ecosystem scientists and land managers [2]. Understanding the relative impacts of climate and land-use change on wetland hydrology is critical for developing land-management strategies for ensuring the sustainability of prairie-pothole wetlands.

The interaction between climate and land-use change has been hypothesized to substantially reduce the productivity of prairie wetlands [11,12]. Dahl [5] summarized how prairie-pothole wetlands have changed in the U.S. portion of the PPR from 1997 to 2009 and presented evidence of how climate and land-use drivers impact prairie-pothole wetlands separately, but he did not discuss interacting effects or present any studies that quantified the relative effects of climate and land-use change. Anteau [13] developed hypotheses about how consolidation drainage can impact wetlands receiving drainage water under different climate regimes but has not tested these hypotheses. Developing novel approaches to measuring the relative impacts of both climate and land use drivers as well as the antagonistic or synergistic interactions among drivers in the PPR has been identified as a critical conservation priority for managing an ecosystem of continental importance [14]

\subsection{History of Prairie-Pothole Wetland Climate and Land-Use Change Research}

There is a rich history of prairie-pothole wetland research spanning almost six decades. A key understanding of prairie-pothole wetland ecology comes from empirical and predictive modeling conducted and developed from long-term research sites. Many of the research examples come from three, long-term, wetland-research sites in the PPR, where hydrology and geochemistry have been continuously measured. From north to south, these sites are St. Denis in south-central Saskatchewan (est. 1968), the Cottonwood Lake Study Area (CLSA) in east-central North Dakota (est. 1968), and Orchid Meadows in eastern South Dakota (est. 1986) [15]. 


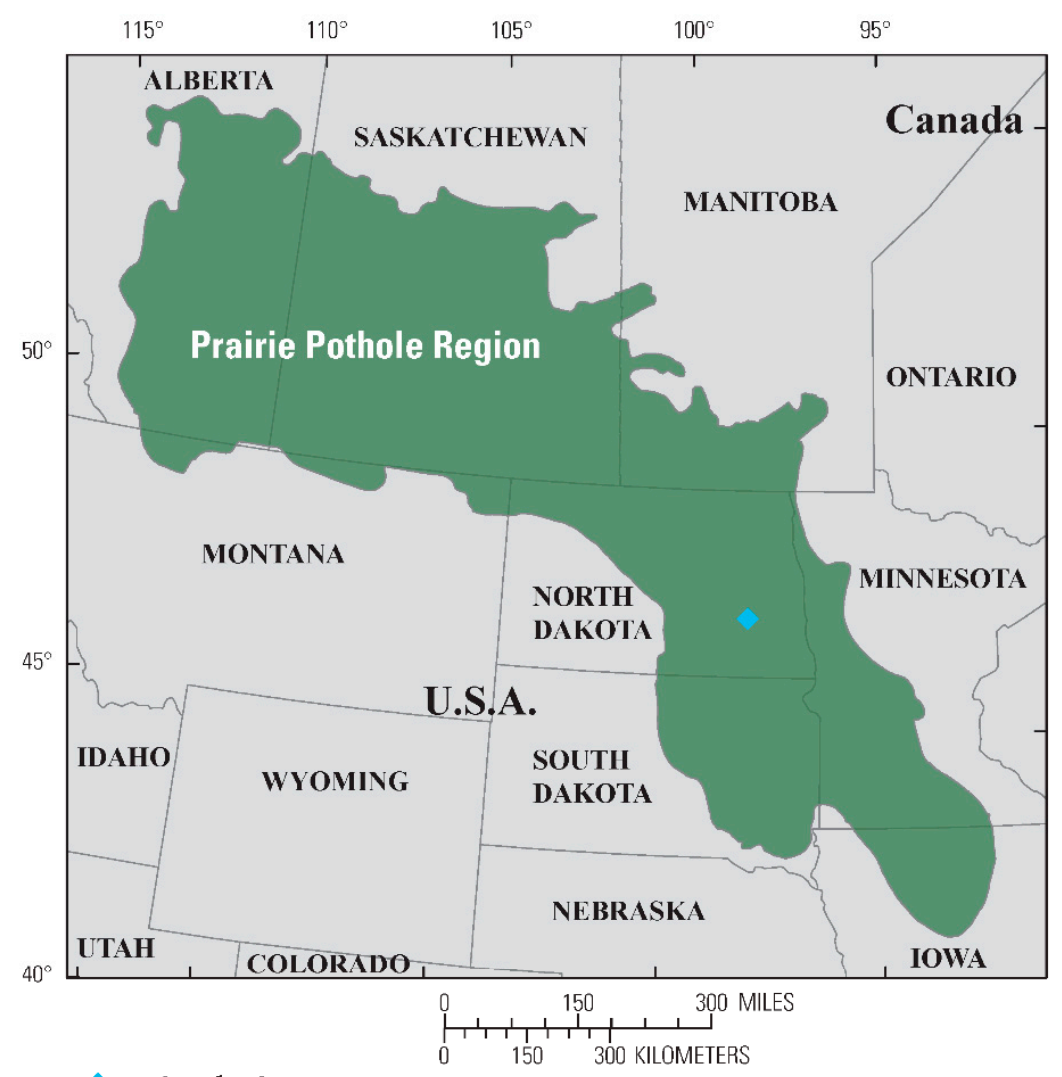

Study Site

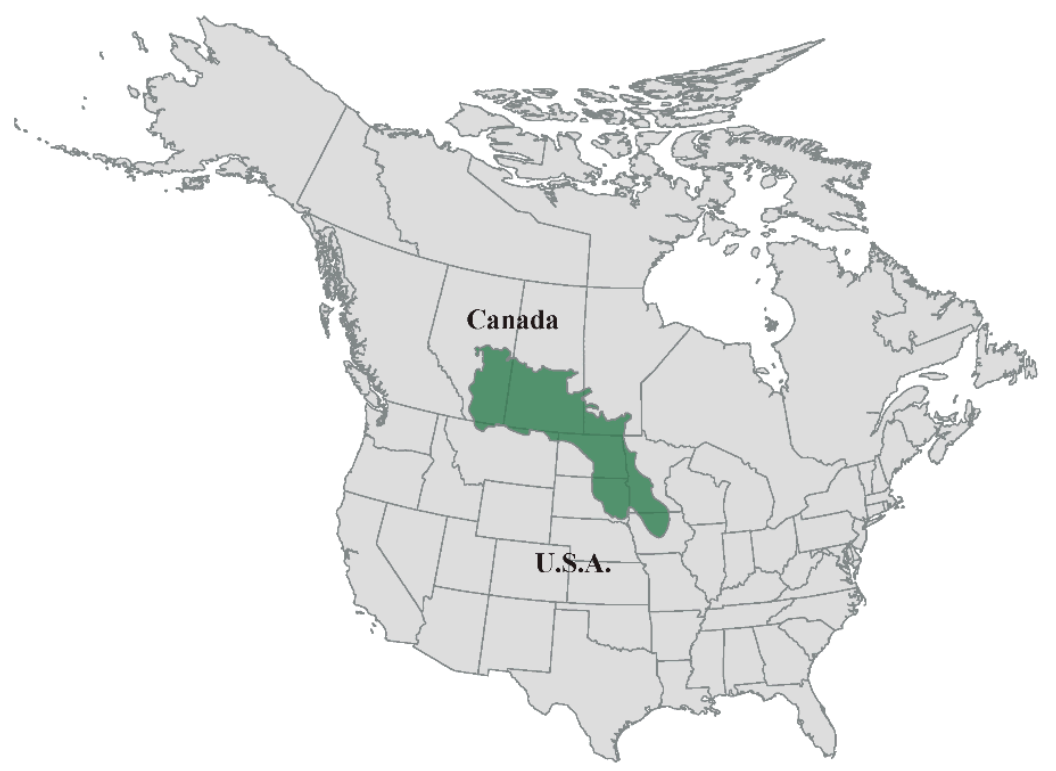

Figure 1. North American Prairie Pothole Region with study site identified with blue diamond adapted from Renton et al. [16]. Bottom panel is the full extent of the continental USA and Canada. Top panel is a zoomed-in extent on the bottom panel.

\subsubsection{Hydrology of the Prairie Pothole Region}

Overall, the position of a wetland relative to groundwater determines the hydrologic and chemical response of that wetland to changes in climate [17]. Wetlands whose ponds lose water to groundwater are considered recharge wetlands, from the perspective of groundwater recharge. Wetlands that both receive water from and lose water to groundwater are considered flow-through wetlands. Wetlands 
that receive water inputs from groundwater are considered discharge wetlands [18]. During periods of extreme drought, discharge wetlands can shift from a groundwater discharge to recharge function, allowing salts dissolved in surface runoff to move into wetland sediments beneath the bathymetric low of the basin [19]. Discharge of drought-derived saline groundwater has the potential to increase the salinity of wetland ponds during wet climate [20]. After a sustained shift towards a wetter climate, there is a general tendency for recharge wetlands to remain low in solutes [17]. The initial pulse of atmospheric water during a wet period can dilute salinity concentrations in discharge wetlands, but discharge wetlands may accumulate a greater mass of solutes [21]. The sustained increases in salts that are transported to wetlands during conditions of high water, either by surface flow from an adjacent pond [22] or groundwater input [21] can lead to a shift in the position that a wetland occupies along the wetland continuum [23] because of the increase in solute input relative to solute loss by flow out of the pond.

Prairie-pothole-wetland water budgets are highly dependent on atmospheric inputs and especially surface runoff. Historically, snowmelt could account for as much as $90 \%$ of the total surface runoff when soils are frozen [24]. Additionally, increased soil moisture during fall would contribute to frost seals in the soil that enhance spring runoff events. Precipitation increases during summer and fall have a compounded effect on runoff when intense rainfall from thunderstorms occurs when soils are saturated [25].

\subsubsection{Climate Drivers}

The climate of the PPR is temperate continental with a great degree of spatial and temporal variability $[26,27]$. Generally, the climate is semiarid with annual potential evapotranspiration exceeding annual precipitation [28]. Annual precipitation displays patterns of high variability on an interannual scale [28], as well as decadal oscillations between wet and dry modes [29] that strongly affect the hydrological status of the region's wetlands [30]. Prairie-pothole wetland hydrology is highly sensitive to changes in precipitation and temperature [30-32]. The spatial variability of ponded wetlands throughout the PPR is also influenced by the agricultural intensity and number of wetlands that have experienced surface and subsurface drainage. Warmer and drier climates combined with continued land-use change in the PPR threaten the long-term sustainability of these wetland ecosystems that are critically important for a diverse set of taxa and services that are both intrinsically important and highly valued by society.

Much of the PPR in the United States (US) has been in a "wet period" since 1993 [30] (Figure 2). More recently, these wet conditions have extended north into the eastern portions of the Canadian PPR [28]. These increasingly wet conditions across the PPR can affect the amount and rate of runoff generated by snowmelt and high-intensity rainstorms [33,34]. Additionally, the wet conditions affecting the PPR coincide with air temperatures that are increasing by about 0.14 degrees Celsius $\left({ }^{\circ} \mathrm{C}\right)$ per decade [35]. Overall, the current 26-year wet period has been greater in magnitude and has persisted longer than any wet period in the Prairie Pothole Region during the last century [30] and perhaps the last 500 years [29]. This climate shift has distinctly altered the surface-runoff dynamics of aquatic and terrestrial systems of the PPR [30] and is predicted to continue [36]. 


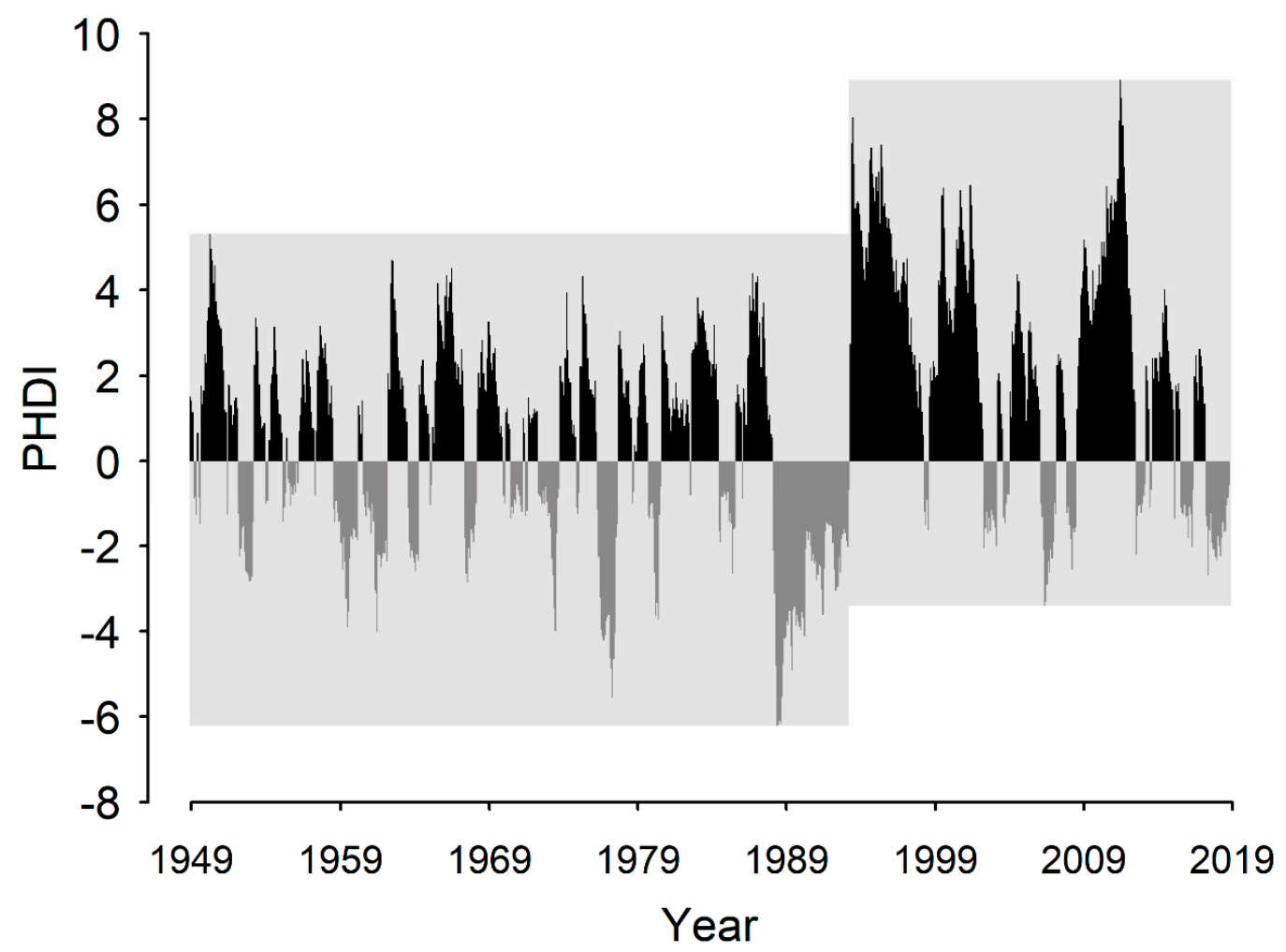

Figure 2. Monthly Palmer Hydrological Drought Index values for Climate Division 5 in southcentral North Dakota (1949-2018). Negative values are represented by gray lines and positive values are represented by black lines. Light gray boxes show the min and max values for each climate period.

Prairie-pothole wetlands are hydrologically sensitive to changes in precipitation and temperature due to their small size, dependence on surface-water runoff and highly variable precipitation inputs, and the region's semiarid climate [28,37]. Moreover, the relatively closed-basin nature of most prairie-pothole wetlands allows for the local expansion and contraction of surface water in response to changes in climate without outflow to larger riverine systems [38]. Observed historical records at the three long-term wetland study sites show that small reductions in precipitation can result in limited wetland ponding, and wet periods can exponentially increase the amount of precipitation that runs off upland areas and sustains wetland ponds for much longer periods $[15,29,39]$. Observations at St. Denis indicate that during wet periods increased multiple-day rainfall events cause increased runoff and, when combined with increases in the fraction of snowpack that effectively becomes spring runoff, increases the duration of prairie-pothole wetland ponding [34]. These altered meteorological conditions can persist long enough to be considered climate shifts [30]. When periods of deluge strongly shift the duration of inundation, the permanence class of a wetland and the corresponding chemistry and vegetation community can also change along a continuum [40]. During short-term shifts, temporarily inundated wetlands behave as seasonally inundated wetlands, seasonally inundated as semi-permanently inundated, and semi-permanently inundated as shallow lakes [15]. Longer-term shifts to wetter climates can introduce excess solutes [21] and impact wetland plant communities [41].

Atmospherically-driven changes to hydrology and chemistry also impact the biological community assemblages and trophic structures of prairie-pothole wetlands. The freshening of ponded water can drive a homogenization of macroinvertebrate communities [42]. Wetter climate periods can also cause wetland ponds to spill from their basins or to merge for prolonged periods resulting in a convergence of macroinvertebrate communities [43]. Additionally, the occurrence of fish has increased markedly throughout the PPR over the past several decades [44]. Transitioning to more permanently inundated and less-saline wetlands can increase suitable habitat for the persistence of fish populations, 
facilitate movements of fish among aquatic habitats, and increase a wetland's susceptibility to human translocations of fish [45].

Long-term wetland observations have led to the development of process-based mechanistic models for simulating the effects of climate change on prairie-pothole wetlands [36]. The development of numerical ecosystem-process models began with WETSIM in 1990 [46] and expanded into a more robust model called WETLANDSCAPE in the early 2000s [47]. WETLANDSCAPE has been used to make projections that under the hottest and driest climate scenarios waterfowl habitat would be limited to the wettest area (i.e., the southeastern portion) of the PPR [48]. Another example of a mechanistic model that was developed to incorporate climate and land-use change impacts on prairie-pothole wetland ecosystems is the open-access Pothole Hydrology-Linked Systems Simulator (PHyLiSS). The PHyLiSS model differs from WETLANDSCAPE as it was developed to work for any prairie-pothole wetland, can be modified to simulate diverse wetland-complex configurations, and does not require a priori assignment of wetland classes to specific basins [49].

\subsubsection{Land Use Drivers}

The two major land-use drivers that impact prairie-pothole wetlands are drainage and grassland-to-cropland conversion. Most research regarding the impact of land use on prairie-pothole wetlands has focused on both land-use-change drivers because drainage and grassland to cropland conversion typically occur in tandem. Some areas of the PPR are estimated to have experienced an agricultural conversion of $75 \%-99 \%$ of native-prairie uplands [50] and drainage of $50 \%-90 \%$ of wetlands in the last 150 years [5].

Wetland drainage in the PPR has been primarily surface drainage. However, subsurface drainage of uplands surrounding wetlands in the PPR is increasing [30] and can alter subsurface water flows to wetlands [30,51]. Wetland losses in the PPR have disproportionately impacted small wetlands [52,53], which are usually categorized as seasonally or temporarily ponded wetlands. Small wetlands are known to provide disproportionate contributions to hydrologic, biogeochemical, and ecological functions than would be predicted by their proportional area in any given watershed [4]. Landscapes with more seasonal and temporary wetlands support more pairs of breeding ducks than those comprised of more permanent wetlands, and smaller wetlands support more pairs by area than do larger ones [54]. Moreover, consolidation drainage can have indirect effects by changing the geometry of intact wetlands [55] and regional wetland vegetation by stabilizing deep-water in larger wetlands, thereby reducing the amount of wetlands that contain emergent vegetation such as cattails and in some cases allowing for cattail expansions in wetlands with shallow spill points [56].

Surface drainage of wetlands was disincentivized in the "swampbuster" provision of the 1985 Farm Bill and subsequent Farm Bills. Swampbuster provisions restricted subsidy payments to farmers who drained wetlands [57]. However, by the time the 1985 Farm Bill was passed, an estimated $60 \%$ of all wetland basins in the U.S. portion of the PPR had been drained [5]. The highest rate of wetland drainage occurred in the wettest portion of the PPR located in the Des Moines lobe of Iowa, where an estimated $90 \%$ of wetlands have been drained [5]. Although these legislative efforts have slowed the rate of wetland drainage in the PPR, prairie-pothole wetlands continue to be lost, and agriculture is the primary cause of that loss [5]. In the Minnesota portion of the PPR, an estimated $4.3 \%$ of wetland area has been lost since 1980, with losses varying from $0 \%$ to $15 \%$ among ecoregions [58].

From 2006 to 2011, the U.S. PPR experienced a grass-to-corn/soy conversion rate ranging from $1.0 \%-5.4 \%$ annually with an estimated total conversion of $\sim 5000 \mathrm{~km}^{2}$ [59]. From the $1980 \mathrm{~s}$ to 2011, there was also an estimated loss of prairie-pothole wetlands of $\sim 0.3 \%$ annually due to agricultural expansion [60]. Agricultural expansion and intensification are likely to continue. Future grassland-to-cropland conversion in the PPR is predicted to be heterogeneous, suggesting the potential for spatially targeted conservation programs [61]. Although extant wetlands surrounded by intensively farmed landscapes may not have adequate grassland habitat to host high densities of breeding 
waterfowl, wetlands in intensively farmed landscapes can provide adequate forage for spring migrants if they do not host fish [62].

Grassland-to-cropland conversion alone can lead to more water accumulating on the landscape. At the St. Denis study area, small wetlands with cropped catchments accumulated and retained more spring snowmelt than those wetlands within grassland catchments [63]. Unfortunately, the co-occurrence of drainage and grassland-to-cropland conversion likely moves water from small wetlands into larger wetlands or to local streams [12]. McCauley et al. [64] found the effects of cropping in catchments that are highly drained varied under different climate periods. In wetter periods, the proportion of crops within the catchment did not significantly affect the water surface area. However, in moderate and drier periods catchments with more crops tended to have smaller water surface areas [64]. These findings suggest complex interactions between multiple land-use and climate drivers.

\subsubsection{Objectives and Research Questions}

Our objectives for this study were two-fold. First, we wanted to establish the need for a novel approach to quantify the relative impacts of multiple global-change drivers on prairie-pothole wetlands by presenting an extensive overview of current research in the field. Second, we wanted to demonstrate a novel approach to quantify the relative impacts of multiple global-change drivers on prairie-pothole wetland hydrology. Specifically, within our second objective, we addressed the following research questions: 1) What are the relative effects of climate, and land-use change on the sustainability of prairie-pothole wetlands? and 2) Do the effects of climate and land-use change interact differently under different climatic conditions? To address these research questions, we carried out a case study illustrating one potential approach to studying the relative effect of climate and land-use change on the sustainability of prairie-pothole wetlands. For this case study, we used a mechanistic systems model to simulate prairie-pothole wetland hydrology under wet and dry conditions for a watershed that has undergone a land-use change in the form of consolidation drainage. Consolidation drainage is the selective surface drainage of multiple small wetlands into the lowest elevation wetland [13].

\section{Materials and Methods}

We designed this study to test the relative effects of climate and land-use change on the hydrology of a prairie-pothole wetland complex. Our research approach was to use a process-based wetland model PHyLiSS to estimate water levels in a well-studied watershed containing prairie-pothole wetlands and simulate both climate and land-use change. We used digital elevation model data to delineate wetland basins and the upland contributing area associated with each wetland. We parameterized PHyLiSS for each wetland basin and used daily temperature and precipitation from local weather station data to simulate wetland water levels over a 70-year period (1949-2018) that included multi-year droughts and a three-decade prolonged wet period. We validated wetland water levels using photointerpretation from historical aerial photographs under drained and undrained model simulations. We used these model simulations to address our research questions within the hypothesis testing framework of Gupta et al. [65].

Under the Gupta et al. [65] framework, any effect of changes in climate would result in an expanded or contracted wetland area moving along the same slope and land-use effect would be a change in slope and/or intercept (Figure 3). Our study also tested the conceptual model put forth by Anteau et al. [12] who hypothesized that a terminal wetland in a drained watershed would operate differently during consecutive wet and dry periods. The Anteau et al. [12] conceptual model hypothesizes that the water levels for a terminal wetland in an undrained watershed would wet up and dry down to a magnitude and duration that corresponds to the magnitude and duration of a wet or dry period. In contrast, consolidation drainage would enable a terminal wetland to remain wet for longer after a wet period due to increased inputs from surface-water runoff. 

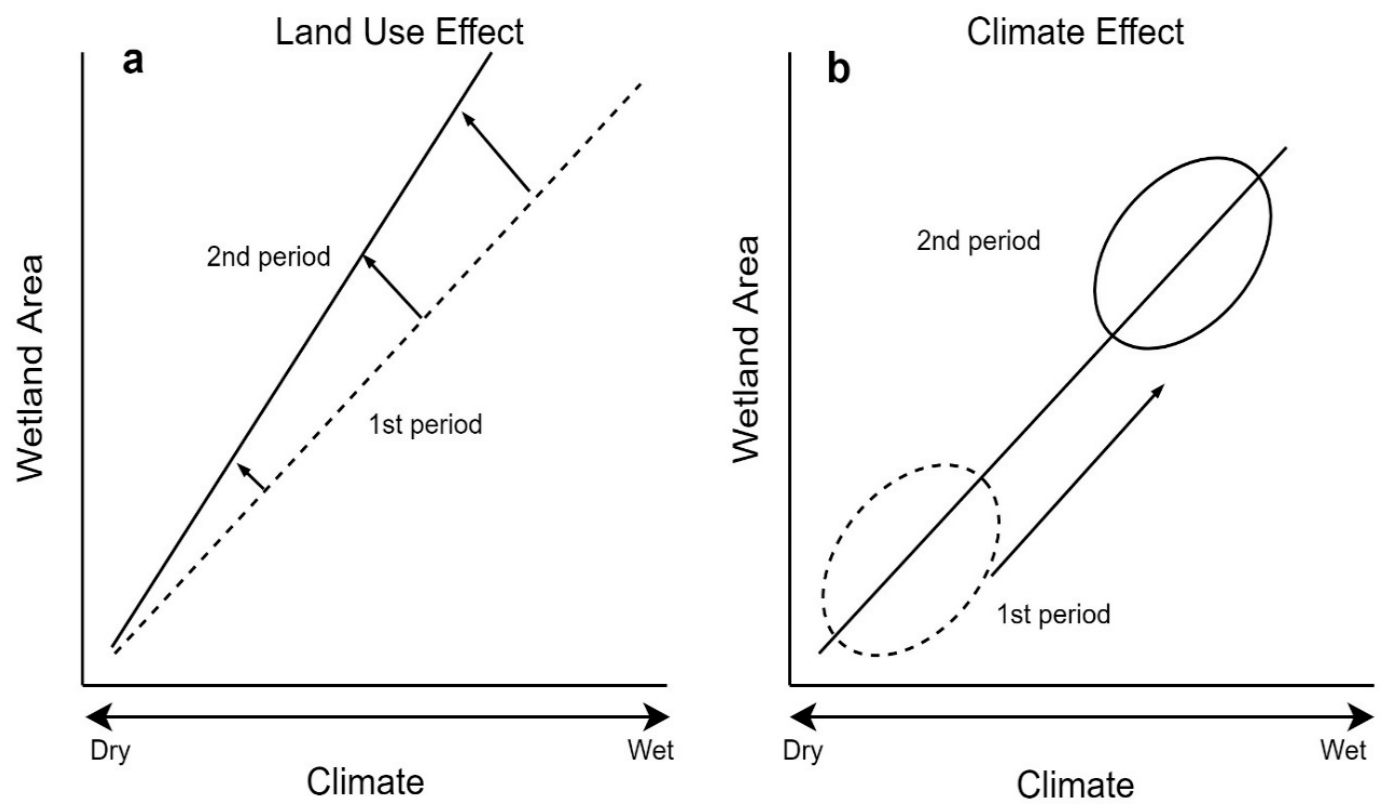

Figure 3. Hypothetical influences of climate and land-use change on wetland area. Adapted from Gupta et al. [65].

\subsection{Study Site}

We chose a case study wetland watershed located north of Valley City, ND, in Barnes County $(47.118 \mathrm{~N}, 97.914 \mathrm{~W})$ consisting of 25 , smaller $(<1 \mathrm{ha})$, seasonally and temporarily ponded wetlands and a single, larger ( $\sim 12 \mathrm{ha})$, semi-permanently ponded wetland at the watershed's terminus (hereafter terminal wetland, Figure 4). Classification of prairie-pothole wetlands is based on water permanence and diagnostic vegetation that forms zones reflective of differing water depths and permanence [66]. Class II, temporarily ponded wetlands typically pond water for a few weeks and have a plant community that consists primarily of wet-meadow vegetation. Class III, seasonally ponded wetlands usually dry by midsummer and have shallow-marsh vegetation that dominates the deepest portions of their basin. Class IV, semi-permanently ponded wetlands frequently have ponded water for the entire year but may dry during years of drought. Deep-marsh emergent and submergent vegetation characterize the deepest areas of Class IV wetlands [66].

The watershed we used in our study has been part of previous research studies focused on wetland hydrology and biological communities $[44,56,64]$. This site was also chosen due to its close proximity to the weather station that is part of the U.S. National Oceanographic and Atmospheric Administration (NOAA) Global Historical Climatological Network (GHCN) [67]. GHCN Station USW00014919 in Jamestown, ND has continuously recorded daily temperature and precipitation from 1 July 1948 to present. 


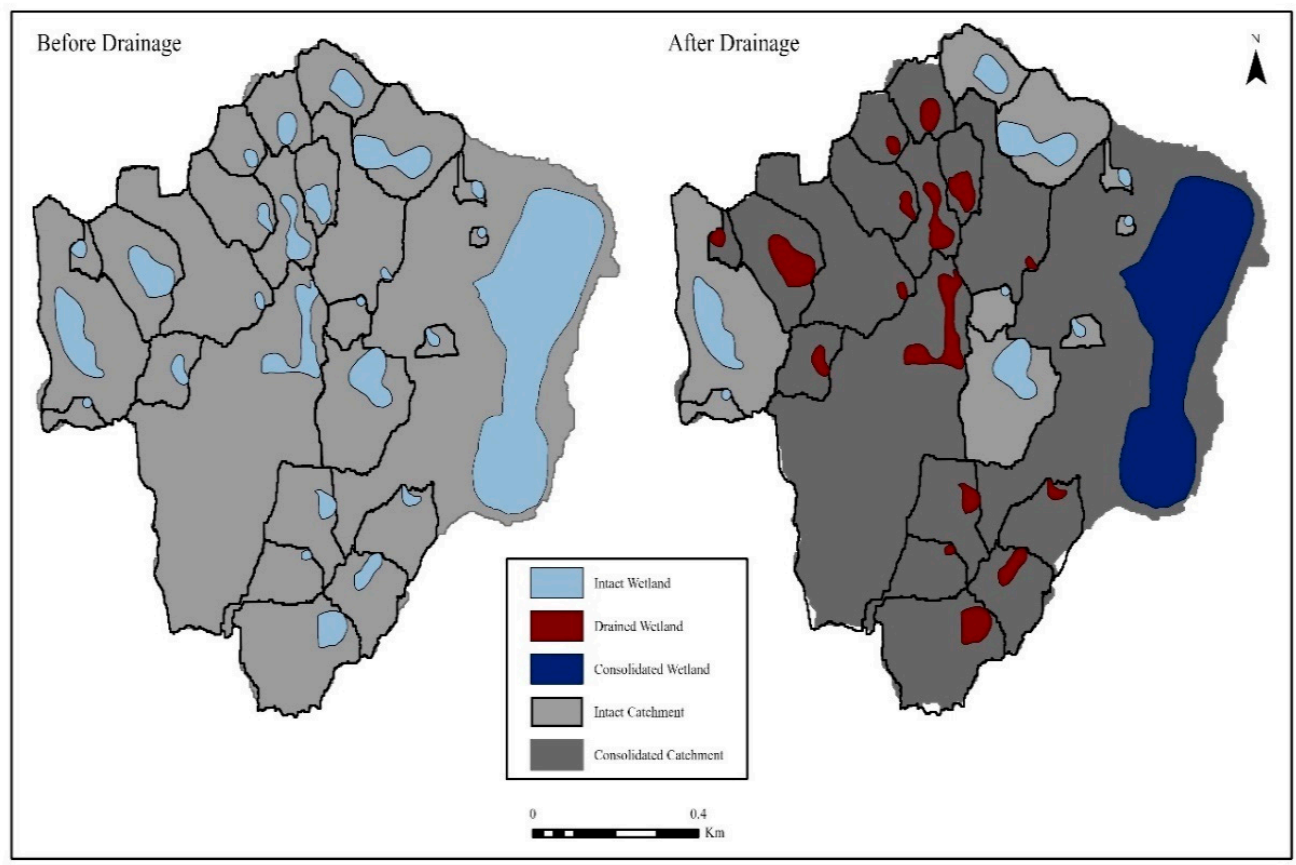

Figure 4. Study Site watershed near Valley City, ND. Left panel shows the wetlands and wetland catchments before consolidation drainage and the right panel shows the wetlands and wetland catchments after consolidation drainage.

\subsection{Wetland and Catchment Delineation}

The 25, smaller ( $<1 \mathrm{ha})$, seasonally and temporarily inundated wetlands were either intact for the extent of our study or drained at some point using a surface ditch network. The digitized wetland areas for the nine intact wetlands and ten drained wetlands were derived from the U.S. Fish and Wildlife Service National Wetlands Inventory (NWI) [68]. The six drained wetlands not included in the NWI database were digitized using historical photographs taken during wet years by McCauley et al. [64]. The terminal wetland ponded extent was delineated from aerial imagery in 16 distinct years 1952-2018 (Figure S1). The imagery was accessed through the U.S. Geological Survey Earth Explorer database, and the images were all from low-altitude aerial surveys acquired at a one-meter ground sample distance (GSD) with a horizontal accuracy that matches within six meters of photo-identifiable ground control points. The images were collected as either Black-and-white, natural color, or color infrared aerial photographs as part of the U.S. Geological Survey's Aerial Photo Single Frame Records Collection [69]. All aerial images were georeferenced using QGIS v3.2.3-Bonn to datum NAD 1983, UTM Zone 14.

We digitized the wetland surface areas in QGIS v3.2.3-Bonn from all available photographs of the terminal wetland. The water-surface area was directly digitized from the photographs when the water boundary was clearly visible. When the water boundary was hidden by emergent vegetation, we calculated the water-surface area as: Area of visible water plus one half of the area of emergent vegetation. Emergent vegetation and water boundaries were ground-truthed in 2010 by Wiltermuth and Anteau [56] and we followed methods established by Lishawa et al. [70] for using ground-truthed data in combination with aerial imagery to determine open water and wetland vegetation in historical years. This method interpolated the water surface boundary as the halfway point between the visible water boundary and the outer edge of the emergent vegetation, which was a method established by McCauley et al. [64].

The entire watershed, including all the study wetlands, was subdivided into contributing areas for each unique wetland basin, intact or drained using procedures similar to those outlined by McCauley and Anteau [71]. Contributing area delineations were accomplished using open-source GIS software package Whitebox Geospatial Analysis Tools (GAT) [72], which performs better than the 
ArcHydro package for "closed basin" systems like prairie-pothole wetlands [73]. Digital Elevation data used to delineate contributing areas were derived from LiDAR-collected 1/9 arc second (three-meter) DEM from the National elevation dataset [74]. McCauley and Anteau [71] showed that there are no significant differences in wetland catchment size found between all DEM types used for delineation. LiDAR-derived three-meter DEM was chosen to reduce processing time while yielding equally accurate wetland catchment boundaries [71]. LiDAR data were collected in the Spring of 2010. We also found that using one-meter LiDAR DEM made for inaccurate delineation of contributing areas due to the very flat slope of the watershed $(0 \%-4 \%)$. Using the Whitebox GAT DEM Pre-processing tools the three-meter DEM depressions were filled to a flat increment value of 0.005. D8 flow pointer and D8 flow accumulation tools were used to create water flow direction data. Finally, waterbody boundaries and the water flow direction data were input into the watershed tool to create discrete boundaries of the area that flow to each water body [71]. Drainage pathways were delineated and digitized from different aerial photos taken between 2000 and 2018.

\subsection{Hydrological Modeling}

We modeled wetland hydrological dynamics using PHyLiSS, which is a daily-timestep systems model designed for exploring the effects of climate and land-use change on prairie-pothole wetland ecosystems [49]. Although PHyLiSS has some capabilities to simulate salinity in wetlands, we only used the hydrological outputs of PHyLiSS. We did not have enough salinity data in our study wetlands to validate model outputs. The hydrological component of PHyLiSS is based on the following water-balance equation:

$$
\mathrm{W}=\mathrm{P}+\mathrm{Q}-\mathrm{E}-\mathrm{T}+\mathrm{Si}-\mathrm{So}+\mathrm{Gi}-\mathrm{Go},
$$

Wetland volume $(\mathrm{W})$ is the volume of ponded water in the wetland pool. Water can be added to a wetland pond by precipitation $(\mathrm{P})$ on the ponded-water surface, runoff $(\mathrm{Q})$ from its local catchment, spill inflow (Si) from adjacent wetland basins, and groundwater inflow (Gi). Runoff can be from rainfall or snowmelt. Water can be lost through evaporation (E), transpiration (T), spill outflow (So) into an adjacent wetland basin, and groundwater outflow (Go).

PHyLiSS inputs used for model simulations included daily average temperature, daily precipitation, wetland basin morphometry, catchment area, and catchment land cover. Precipitation and temperature were derived from NOAA GHCN Station USW00014919 in Jamestown, ND. Precipitation in the form of rain either falls directly on the wetland or the upland with surface runoff being calculated with the Soil Conservation Service runoff curve number method [75]. Land cover was determined from aerial imagery and the remotely-sensed National Land Cover Database for runoff curve number equations as described in McKenna et al. [49]. When air temperatures are lower than $0^{\circ} \mathrm{C}$, precipitation accumulates as a snowpack, which melts when the ten-day mean air temperature is above $2{ }^{\circ} \mathrm{C}$. The snowpack that accumulates over the wetland area goes directly into ponded water, while runoff from the upland snowpack is dependent on the antecedent soil moisture in October of the preceding year as represented by the Palmer Hydrologic Drought Index (PHDI) [76]. Monthly PHDI was derived from the NOAA National Centers for Environmental Information North Dakota Climate Division 5.

Water losses include evapotranspiration, shallow groundwater loss, and overland spill. Evapotranspiration is calculated using the Hamon Equation for potential evapotranspiration [77]. Shallow groundwater losses are accounted for using the equation from Huang et al. [78]. Overland spill occurs when the water level of the wetland pond reaches a low point in the divide between adjacent catchments. To simulate wetland drainage, any ponded water that accumulates in a drained wetland is moved across the drainage path to the next wetland in the watershed. Transmission losses from spill events are relative to the area of the flow path (Figure S2) based on Couturier and Ripley [79] that demonstrated $50 \%-75 \%$ losses in vegetated drains during rainfall events and [80] that demonstrated up to $80 \%$ losses during snowmelt events. These connections are visualized in (Figure 5). Wetland bathymetry (Volume: Area) estimates were used from mean values for wetland type and ecoregion established by Gleason et al. [81]. 
Detailed descriptions and validations of the PHyLiSS model can be found in McKenna et al. [49]. McKenna et al. [49] validated PHyLiSS using daily wetland pond volumes for a number of different sized prairie-pothole wetlands situated along a ground-water gradient under both wet and dry conditions for over three decades.

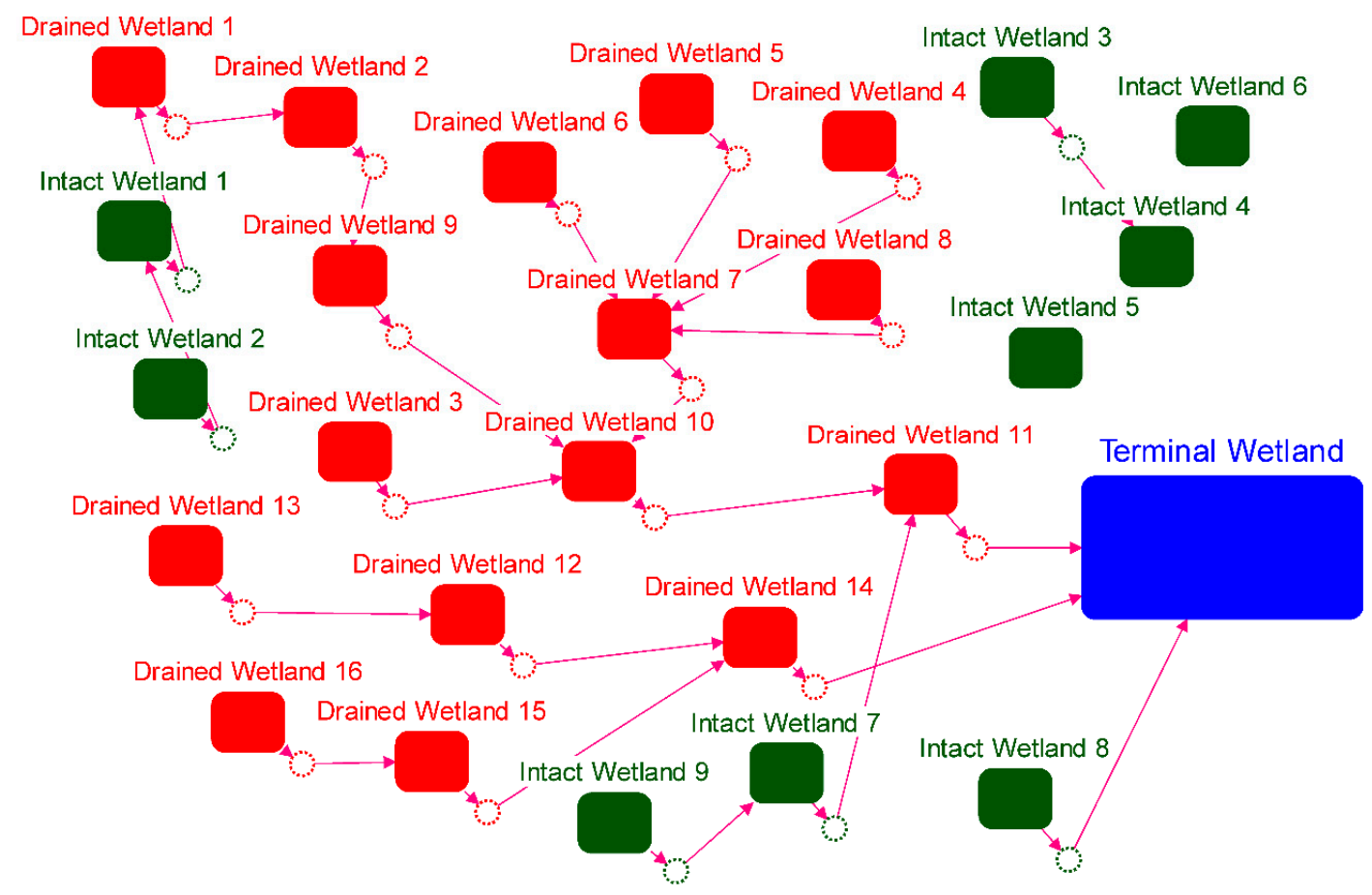

Figure 5. Stella schematic of the modeled wetland complex. Each box represents a wetland with all components of the PHyLiSS model. Red boxes represent drained wetlands and red circles represent flow from drained wetlands, green boxes intact wetlands and green circles represent flow from intact wetlands, and the blue box represents the terminal wetland. Pink arrows connecting a wetland to another wetland represent the spill pathway.

We simulated water volumes and spill events with no drainage inputs and with drained wetlands spilling into flow paths that eventually drain into the terminal wetland. The simulations with no drainage acted as our baseline where we could isolate the impacts on the terminal wetlands due solely to changes in climate. Any changes in wetland area slope or intercept between the undrained and drained simulation were attributed to a drainage effect. We cross-validated the model estimates for wetland area to wetland area observed from delineated aerial imagery.

\section{Results}

We quantified the effects of both climate and land-use change through multiple decades in our case study watershed. Overall the modeled daily wetland area of the terminal wetland was higher when all the drained wetlands were drained in 1949 (Figure 6). Wet years in 1950 and 1953 (Figure 2) coincide with the initial major difference in wetland area between the two simulated land-use change scenarios. From 1953 to 1992 the slopes of the wetland area through time were similar for the two land-use change scenarios. During the extended drought from 1988 to 1992 in the drained scenario, the wetland area slope was $-14.52 \mathrm{~m}^{2}$ per day, and for the undrained scenario, the wetland area change was $-14.86 \mathrm{~m}^{2}$ per day (Figure 6). The differences in wetland area response slope become apparent during an extreme wetting period from 1993 to 2000 (Figure 2, Figure 6). During this period the terminal wetland reaches maximum capacity under both the drained and undrained scenarios. Maximum capacity is reached under the drained scenario in 1995, whereas the wetland in the undrained scenario reaches maximum 
capacity in 1999. The difference in slopes between the two scenarios in those two periods was $18.47 \mathrm{~m}^{2}$ per day for the undrained scenario and $40.14 \mathrm{~m}^{2}$ per day for the drained scenario (Figure 6).

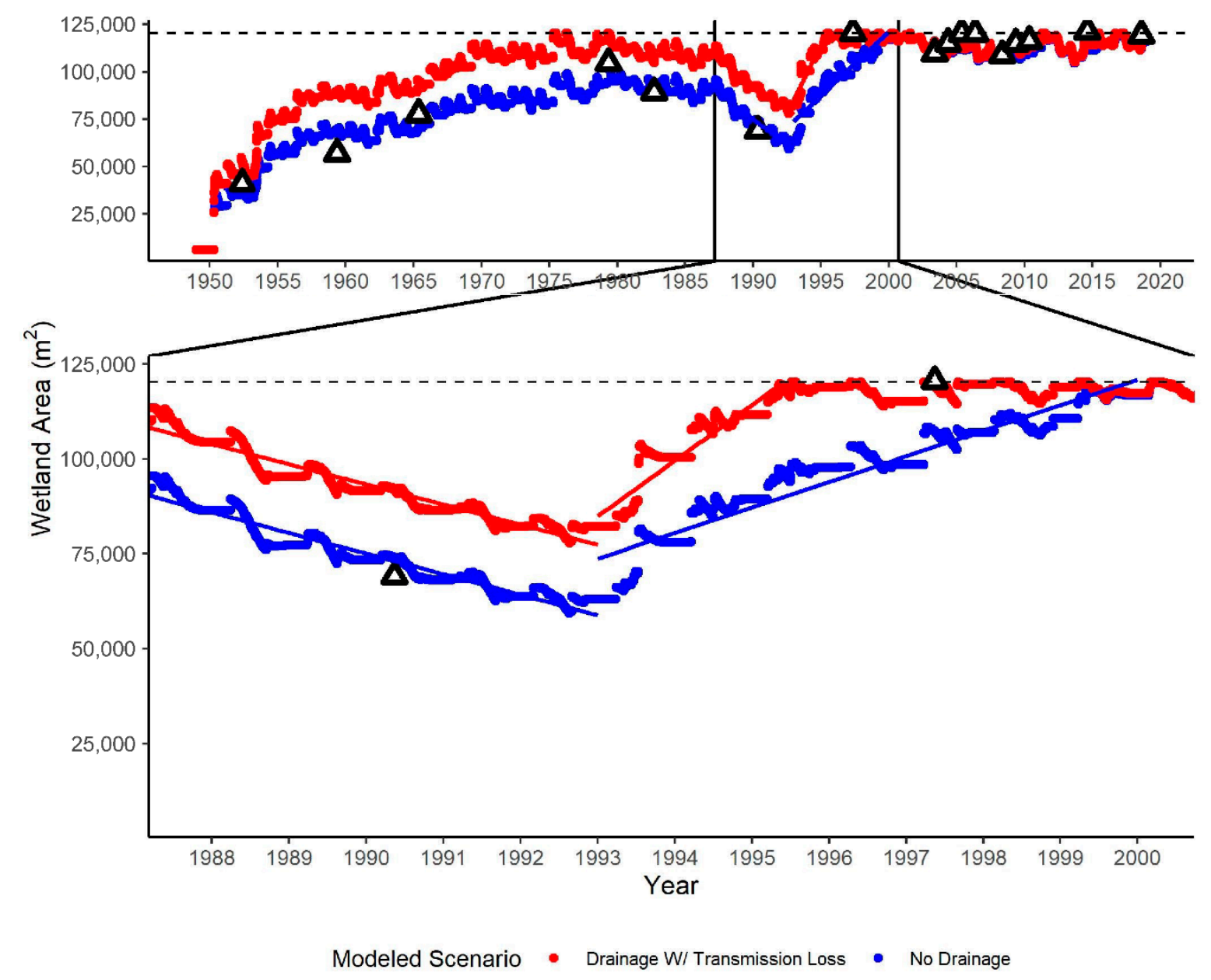

Figure 6. Upper panel shows daily modeled wetland area for the terminal wetland (1949-2018). Red dots represent the no drainage scenario and blue dots represent the drainage scenario, where 16 wetlands are drained into the terminal wetland. Lower panel shows a zoom in on a period of major change (1987-2000). Red and blue solid lines represent best fit lines for the dry down and wet up periods. Black triangles represent observed terminal wetland area delineated from aerial photography. Dashed horizontal line represents the maximum wetland area before water spills from the terminal wetland to an adjacent catchment.

In addition to the changes in slope, we found evidence that land-use change can also impact the intercept of some climate-to-wetland relationships (Figure 7). We found that comparing mean annual PHDI to the wetland area under the undrained scenario results in an intercept of $81,699 \mathrm{~m}^{2}$ area at the lowest PHDI (-3). Under the drained scenario, the intercept was $23 \%$ higher at $106,708 \mathrm{~m}^{2}$ area for the lowest PHDI (-3). The slopes were not comparable because drained scenario wetland area vs PHDI slope was artificially lowered due to the limiting maximum area of the wetland and water that spilled out of the wetland to an adjacent catchment (Figure 8). Our modeling results indicated that water did not spill out of the terminal wetland in either scenario until after 1975 and overall the terminal wetland in the drained scenario spilled 10 times more water than the undrained scenario (Figure 8). 


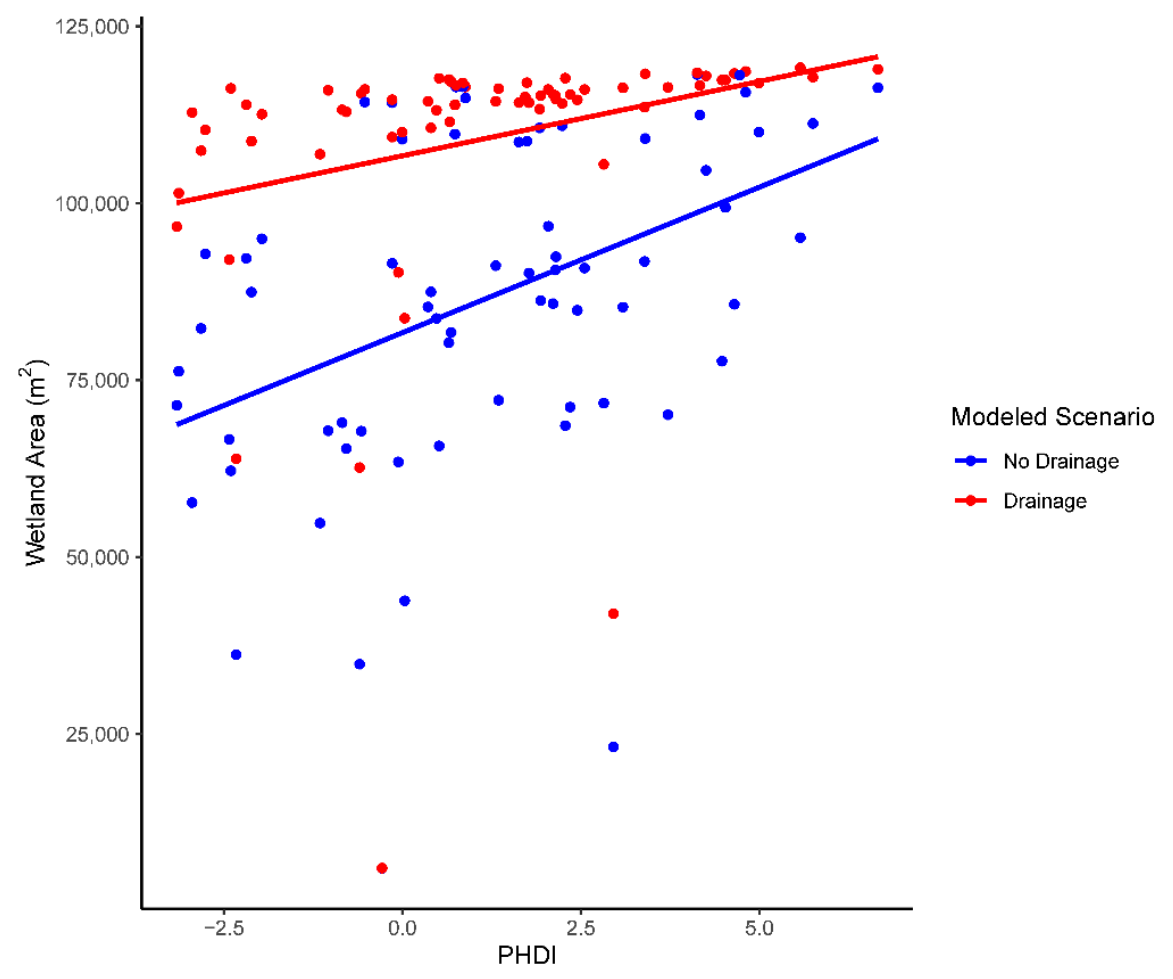

Figure 7. Mean annual terminal wetland area $\left(\mathrm{m}^{2}\right)$ vs. mean annual Palmer Hydrological Drought Index (1949-2018). Blue dots represent the no drainage scenario, where 16 wetlands are drained into the terminal wetland. Red dots represent the drainage scenario where the terminal wetland received zero spills from other wetlands. Solid lines represent best fit relationships for the two scenarios.

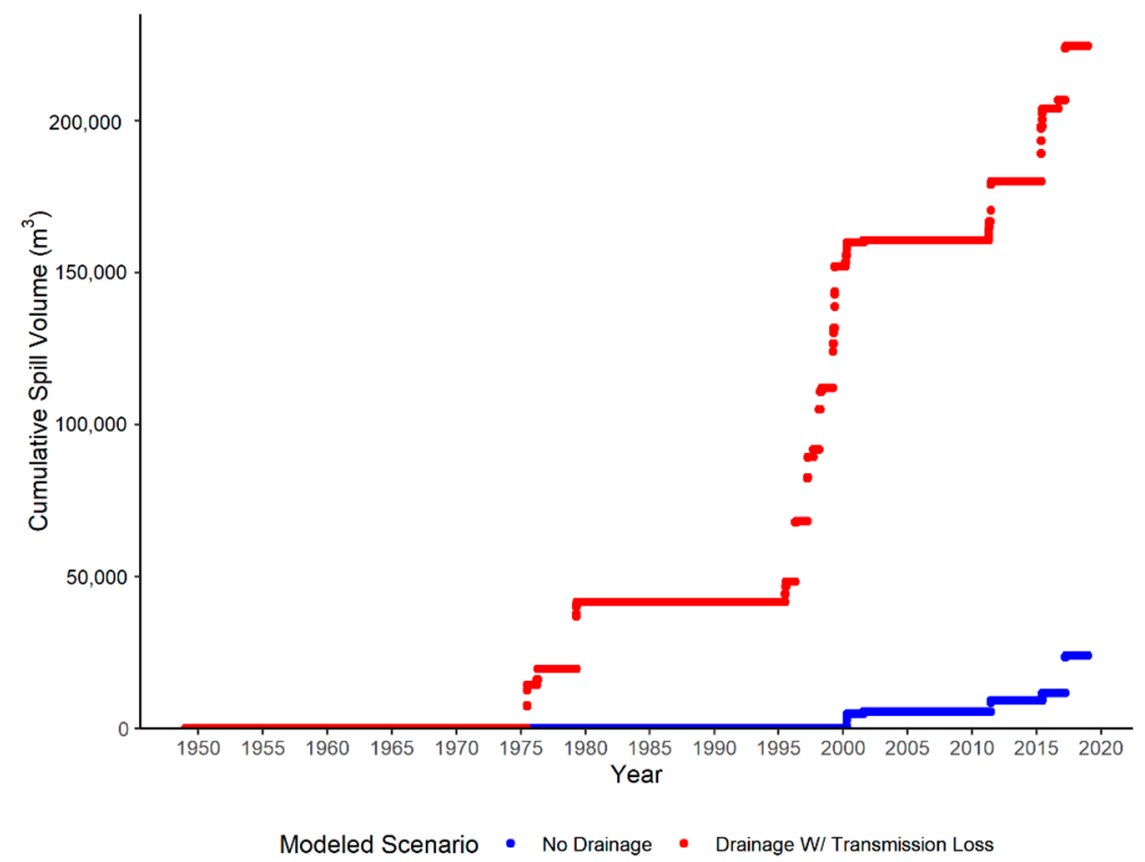

Figure 8. Cumulative water volume $\left(\mathrm{m}^{3}\right)$ spillage since 1949 from the terminal wetland under drained and un-drained scenarios. The blue dots represent the daily cumulative spill volume of the un-drained scenario and the red dots represent the daily cumulative spill volume under the drained scenario.

It is unclear from aerial photographs exactly when wetland drainage occurred in the case study catchment. The model output for wetland area matches closest to the undrained scenario from the 
beginning of the aerial photographic record in 1952 through the 1990 photograph (Table 1). At the time of the 1997 photograph, the drained scenario wetland area was $0.7 \%$ less than the observed area, while the undrained scenario wetland area was $11.2 \%$ less than the observed area. When drainage is assumed to occur on 1 January 1993, the modeled output for terminal wetland area averaged $1.8 \%$ difference from 16 observed wetland areas (Figure 9, Table 1). Overall model uncertainty was $~ 5 \%$ difference in wetland area relative to aerial photograph interpretation. This estimate was taken by averaging the absolute \% difference between the modeled wetland area and the observed wetland area derived from delineation of aerial photographs.

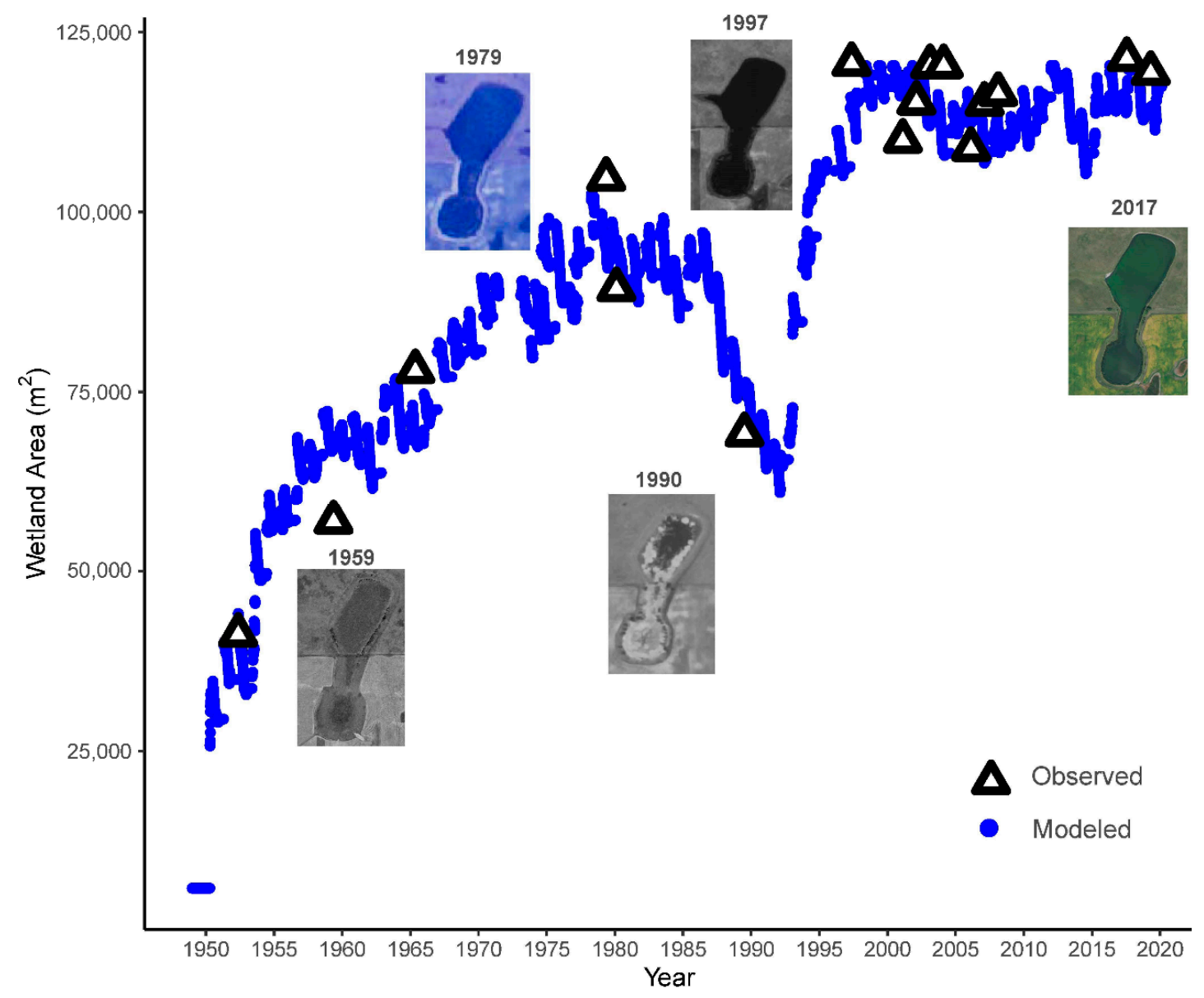

Figure 9. Daily modeled wetland area for the terminal wetland (1949-2018) with drainage starting 1 January 1993. White triangles represent observed terminal wetland area delineated from aerial photography. 
Table 1. Comparison of modeled wetland area vs. observed wetland area delineated from aerial photography. Undrained scenario numbers were used for the final model run before 1993 and drained scenario numbers were used after 1993.

\begin{tabular}{cccc}
\hline Year & Observed Area $\left.\mathbf{( m}^{\mathbf{2}}\right)$ & $\begin{array}{c}\text { Undrained Scenario } \% \\
\text { Difference from Observed }\end{array}$ & $\begin{array}{c}\text { Drained Scenario \% Difference } \\
\text { from Observed }\end{array}$ \\
\hline 1952 & 41231 & $1.9 \%$ & $+67.2 \%$ \\
1959 & 56885 & $19.8 \%$ & $+104.8 \%$ \\
1965 & 77903 & $-5.1 \%$ & $+51.5 \%$ \\
1979 & 104638 & $-2.2 \%$ & $+14.7 \%$ \\
1982 & 89312 & $6.5 \%$ & $+25.9 \%$ \\
1990 & 69142 & $6.5 \%$ & $+42.9 \%$ \\
1997 & 120619 & $-11.2 \%$ & $-0.7 \%$ \\
2003 & 109949 & $+4.9 \%$ & $4.9 \%$ \\
2004 & 115246 & $-3.5 \%$ & $-2.5 \%$ \\
2005 & 120312 & $-5.8 \%$ & $-2.4 \%$ \\
2006 & 120312 & $-6.3 \%$ & $-2.9 \%$ \\
2008 & 108811 & $+0.2 \%$ & $5.2 \%$ \\
2009 & 115099 & $-1.1 \%$ & $4.0 \%$ \\
2010 & 116466 & $-3.9 \%$ & $1.3 \%$ \\
2014 & 121302 & $-7.4 \%$ & $-4.0 \%$ \\
2018 & 119369 & $-4.6 \%$ & $-1.9 \%$ \\
\hline
\end{tabular}

\section{Discussion}

Based on simulations from our process-based model, we found evidence of synergistic interaction of land use and climate on the water-surface area of wetlands in a watershed within the PPR. From simulating the land-use change of wetland consolidation drainage over a period of climate change we were able to parse out the relative impacts of the two global change drivers on the hydrology of a terminal prairie-pothole wetland. We quantified these relative differences under the hypothesis testing framework of Gupta et al. [65] where land-use change shows a change in the slope of a given response variable and climate change occurs as a change in magnitude along the same slope. We found that during wet years after drainage the terminal wetland is much more sensitive to areal expansion when upland wetlands are drained, although under a wetting event as strong as observed from 1993 to 2000 (Figure 2) the wetland area would have eventually expanded to its maximum, spill-point limited size and maintained that size without any consolidation drainage (Figure 7).

Consolidation drainage sped up wetland expansion to the spill point by four years, which caused an order of magnitude more water to spill out of the wetland than would have with no drainage. If these surface-water losses were able to travel far enough their certainly would have been increased floodwater in nearby rivers and streams, or in the case of Devils Lake, ND [35] expanded a larger terminal wetland that caused extensive flooding of uplands. Both climate and agricultural land-use change have been shown to be occurring as streamflow has been increasing throughout many states of the upper midwestern United States [65]. These findings are similar to the observations of Haque et al. [82] that consolidated wetlands were more susceptible to spillage than intact wetlands due to higher antecedent water levels in consolidated wetlands. Haque et al. [82] also found that water tables downslope of drained wetlands responded very sensitively to precipitation suggesting the potential for enhanced subsurface connectivity in watersheds with wetland drainage. These down-watershed impacts on streams can be compounded as increasingly wet conditions cause higher antecedent soil moisture conditions and amplify the amount of surface runoff that is generated by both snowmelt and high-intensity rainstorms [33].

In the Canadian PPR, changes in snowmelt dynamics, increased multi-day extreme precipitation events, and wetland drainage are hypothesized to be interacting to cause an observed 14-fold increase in streamflow volumes and a 12-fold increase in runoff ratios [33]. This rapid shift in hydrology is likely due to a non-linear or threshold-like response to combinations of a changing climate, exacerbated 
by changes in land use and recent increases in drainage. However, these relative impacts of and interactions between climate and land-use drivers have yet to be quantified.

Although the impacts of drainage on terminal wetland size may be most easy to observe during a wet period (Figure 7), we found the effects of short-duration flood events could persist well past the event (Figure 7). Short pulses of extra water become multiplicative when many upland wetlands are drained directly into the terminal wetland. This effect can be seen in Figure 8, where the wetland area remains very elevated across years of varied climate in the drained scenario as compared to the undrained scenarios. Extreme precipitation events are projected to increase under climate change in the PPR [83], and our findings suggest these larger events can have multi-decadal hydrological impacts that are greatly magnified when extensive consolidation exists on the landscape.

Other mechanistic and statistical models have been developed to generate hypotheses and project future impact of climate on prairie-pothole wetlands as well. These approaches include an examination of wetland bird geographic ranges and how they may expand, contract, or shift regionally, under future climates $[7,84]$. Other approaches are to use remote sensing techniques to measure and project the response of wetland numbers and area across the PPR to current and future climates $[85,86]$ and to determine how connections among wetlands may be altered by climate change [87]. Overall, modeling efforts agree that a warmer climate without increased precipitation would have a negative impact on the sustainability of prairie-pothole wetlands [36,88]. A more widely distributed application of our approach will help further the understanding of how synergistic effects of both climate and land-use change propagate on a landscape scale. This broader understanding will help land managers plan for a future that includes both climate and land-use change.

With growing recognition of the existence of interactions between global change drivers, conservation strategies and biodiversity projections that only address a single driver are inadequate. Future research needs to understand and quantify the major mechanisms by which global change drivers interact, in order to minimize risks and increase opportunities for the conservation of biodiversity [2]. Our findings show one example of using a process-based mechanistic model and historical aerial imagery to quantify impacts of both climate and land-use change on wetlands and watershed hydrology. A broader application of this methodology can help land managers understand the hydrological implications of future changes in climate on watersheds that contain drained wetlands.

\section{Conclusions}

- We successfully developed and validated a modeling framework for quantifying the relative effects of both climate and land-use change on a watershed in the PPR.

- Wetland hydrology responds best to the impacts of consolidation drainage during wet climate periods.

- Sustained wet periods can impact a terminal wetland similarly with or without drainage. However, drainage increased the rate at which the terminal wetland reached its spill point by years, and excess spill from a terminal wetland can have down-stream flooding implications.

Supplementary Materials: The following are available online at http://www.mdpi.com/2071-1050/11/23/6581/s1, Figure S1 and Figure S2.

Author Contributions: Conceptualization, O.P.M., S.R.K., D.M.M., M.J.A. and M.T.W.; methodology, O.P.M., S.R.K., D.M.M., M.J.A. and M.T.W.; formal analysis, O.P.M., S.R.K.; writing-original draft preparation, O.P.M.; writing-review and editing, O.P.M., S.R.K., D.M.M., M.J.A. and M.T.W.; visualization, O.P.M., S.R.K.; funding acquisition, D.M.M.

Funding: This research was funded by the U.S. Geological Survey Climate Research and Development Program.

Acknowledgments: We thank Nadia Noori for assistance on GIS map preparation. Any use of trade, firm, or product names is for descriptive purposes only and does not imply endorsement by the U.S. government. We also thank Max Post van der Burg and 3 anonymous reviewers for their constructive feedback that greatly improved this paper.

Conflicts of Interest: The authors declare no conflict of interest. 


\section{References}

1. Creed, I.F.; Lane, C.R.; Serran, J.N.; Alexander, L.C.; Basu, N.B.; Calhoun, A.J.K.; Christensen, J.R.; Cohen, M.J.; Craft, C.; D'Amico, E.; et al. Enhancing protection for vulnerable waters. Nat. Geosci. 2017, 10, 809. [CrossRef]

2. Oliver, T.H.; Morecroft, M.D. Interactions between climate change and land use change on biodiversity: Attribution problems, risks, and opportunities. Wires Clim. Chang. 2014, 5, 317-335. [CrossRef]

3. Yalcin, S.; Leroux, S.J. An empirical test of the relative and combined effects of land-cover and climate change on local colonization and extinction. Glob. Chang. Biol. 2018, 24, 3849-3861. [CrossRef] [PubMed]

4. Calhoun, A.J.K.; Mushet, D.M.; Bell, K.P.; Boix, D.; Fitzsimons, J.A.; Isselin-Nondedeu, F. Temporary wetlands: Challenges and solutions to conserving a 'disappearing' ecosystem. Biol. Conserv. 2017, 211, 3-11. [CrossRef]

5. Dahl, T.E. Status and Trends of Prairie Wetlands in the United States 1997 to 2009; U.S. Fish \& Wildlife Service: Washington, DC, USA, 2014; p. 67.

6. Balas, C.J.; Euliss, N.H.; Mushet, D.M. Influence of Conservation Programs on Amphibians using Seasonal Wetlands in the Prairie Pothole Region. Wetlands 2012, 32, 333-345. [CrossRef]

7. Steen, V.; Skagen, S.K.; Noon, B.R. Vulnerability of Breeding Waterbirds to Climate Change in the Prairie Pothole Region, U.S.A. PLoS ONE 2014, 9, e96747. [CrossRef] [PubMed]

8. Ando, A.W.; Mallory, M.L. Optimal portfolio design to reduce climate-related conservation uncertainty in the Prairie Pothole Region. Proc. Natl. Acad. Sci. USA 2012, 109, 6484. [CrossRef] [PubMed]

9. Marton, J.M.; Creed, I.F.; Lewis, D.B.; Lane, C.R.; Basu, N.B.; Cohen, M.J.; Craft, C.B. Geographically Isolated Wetlands are Important Biogeochemical Reactors on the Landscape. Bioscience 2015, 65, 408-418. [CrossRef]

10. Gleason, R.A.; Euliss, N.H.; Tangen, B.A.; Laubhan, M.K.; Browne, B.A. USDA conservation program and practice effects on wetland ecosystem services in the Prairie Pothole Region. Ecol. Appl. 2011, 21, S65-S81. [CrossRef]

11. Rashford, B.S.; Adams, R.M.; Wu, J.; Voldseth, R.A.; Guntenspergen, G.R.; Werner, B.; Johnson, W.C. Impacts of climate change on land-use and wetland productivity in the Prairie Pothole Region of North America. Reg. Environ. Chang. 2016, 16, 515-526. [CrossRef]

12. Anteau, M.J.; Wiltermuth, M.T.; van der Burg, M.P.; Pearse, A.T. Prerequisites for Understanding Climate-Change Impacts on Northern Prairie Wetlands. Wetlands 2016, 36, 299-307. [CrossRef]

13. Anteau, M.J. Do Interactions of Land Use and Climate Affect Productivity of Waterbirds and Prairie-Pothole Wetlands? Wetlands 2012, 32, 1-9. [CrossRef]

14. Yocum, H.M.; Ray, A.J. Climate information to support wildlife management in the North Central United States. Reg. Environ. Chang. 2019, 19, 1187-1199. [CrossRef]

15. Johnson, W.C.; Boettcher, S.E.; Poiani, K.A.; Guntenspergen, G. Influence of weather extremes on the water levels of glaciated prairie wetlands. Wetlands 2004, 24, 385-398. [CrossRef]

16. Renton, D.A.; Mushet, D.M.; DeKeyser, E.S. Climate Change and Prairie Pothole Wetlands: Mitigating Water-Level and Hydroperiod Effects through Upland Management; 2015-5004; US Department of the Interior: Washington, DC, USA, 2015; p. 32.

17. Cressey, R.L.; Austin, J.E.; Stafford, J.D. Three Responses of Wetland Conditions to Climatic Extremes in the Prairie Pothole Region. Wetlands 2016, 36, 357-370. [CrossRef]

18. Sloan, C.E. Ground-Water Hydrology of Prairie Potholes in North Dakota; 585C; US Government Printing Office: Washington, DC, USA, 1972.

19. Levy, Z.F.; Rosenberry, D.O.; Moucha, R.; Mushet, D.M.; Goldhaber, M.B.; LaBaugh, J.W.; Fiorentino, A.J.; Siegel, D.I. Drought-induced recharge promotes long-term storage of porewater salinity beneath a prairie wetland. J. Hydrol. 2018, 557, 391-406. [CrossRef]

20. Levy, Z.F.; Mills, C.T.; Lu, Z.L.; Goldhaber, M.B.; Rosenberry, D.O.; Mushet, D.M.; Lautz, L.K.; Zhou, X.L.; Siegel, D.I. Using halogens $(\mathrm{Cl}, \mathrm{Br}, \mathrm{I})$ to understand the hydrogeochemical evolution of drought-derived saline porewater beneath a prairie wetland. Chem. Geol. 2018, 476, 191-207. [CrossRef]

21. LaBaugh, J.W.; Mushet, D.M.; Rosenberry, D.O.; Euliss, N.H.; Goldhaber, M.B.; Mills, C.T.; Nelson, R.D. Changes in Pond Water Levels and Surface Extent Due to Climate Variability Alter Solute Sources to Closed-Basin Prairie-Pothole Wetland Ponds, 1979 to 2012. Wetlands 2016, 36, 343-355. [CrossRef]

22. Nachshon, U.; Ireson, A.; van der Kamp, G.; Davies, S.R.; Wheater, H.S. Impacts of climate variability on wetland salinization in the North American prairies. Hydrol. Earth Syst. Sci. 2014, 18, 1251-1263. [CrossRef] 
23. Mushet, D.M.; McKenna, O.P.; LaBaugh, J.W.; Euliss, N.H.; Rosenberry, D.O. Accommodating State Shifts within the Conceptual Framework of the Wetland Continuum. Wetlands 2018, 38, 1-5. [CrossRef]

24. Pomeroy, J.; Gray, D.; Shook, K.; Toth, B.; Essery, R.; Pietroniro, A.; Hedstrom, N. An evaluation of snow accumulation and ablation processes for land surface modelling. Hydrol. Process. 1998, 12, 2339-2367. [CrossRef]

25. LaBaugh, J.W.; Rosenberry, D.O.; Mushet, D.M.; Neff, B.P.; Nelson, R.D.; Euliss, N.H. Long-term changes in pond permanence, size, and salinity in Prairie Pothole Region wetlands: The role of groundwater-pond interaction. J. Hydrol. Reg. Stud. 2018, 17, 1-23. [CrossRef]

26. Mushet, D.M. Midcontinent Prairie-Pothole Wetlands and Climate Change: an Introduction to the Supplemental Issue. Wetlands 2016, 36, 223-228. [CrossRef]

27. Winter, T.C. Hydrological, Chemical, and Biological Characteristics of a Prairie Pothole Wetland Complex under Highly Variable Climate Conditions: The Cottonwood Lake Area, East-Central North. Dakota; Geological Survey (USGS): Reston, VA, USA, 2003.

28. Hayashi, M.; van der Kamp, G.; Rosenberry, D.O. Hydrology of prairie wetlands: understanding the integrated surface-water and groundwater processes. Wetlands 2016, 36, 237-254. [CrossRef]

29. Winter, T.C.; Rosenberry, D.O. Hydrology of Prairie Pothole Wetlands during Drought and Deluge: A 17-Year Study of the Cottonwood Lake Wetland Complex in North Dakota in the Perspective of Longer Term Measured and Proxy Hydrological Records. Clim. Change 1998, 40, 189-209. [CrossRef]

30. McKenna, O.P.; Mushet, D.M.; Rosenberry, D.O.; LaBaugh, J.W. Evidence for a climate-induced ecohydrological state shift in wetland ecosystems of the southern Prairie Pothole Region. Clim. Chang. 2017, 145, 273-287. [CrossRef]

31. Niemuth, N.D.; Wangler, B.; Reynolds, R.E. Spatial and temporal variation in wet area of wetlands in the Prairie Pothole Region of North Dakota and South Dakota. Wetlands 2010, 30, 1053-1064. [CrossRef]

32. Larson, D.L. Effects of Climate on Numbers of Northern Prairie Wetlands. Clim. Chang. 1995, 30, 169-180. [CrossRef]

33. Dumanski, S.; Pomeroy, J.W.; Westbrook, C.J. Hydrological regime changes in a Canadian Prairie basin. Hydrol. Process. 2015, 29, 3893-3904. [CrossRef]

34. Shook, K.; Pomeroy, J. Changes in the hydrological character of rainfall on the Canadian prairies. Hydrol. Process. 2012, 26, 1752-1766. [CrossRef]

35. Todhunter, P.E. Mean hydroclimatic and hydrological conditions during two climatic modes in the Devils Lake Basin, North Dakota (USA). Lakes Reservoirs Sci. Policy Manag. Sustain. Use 2016, 21, 338-350. [CrossRef]

36. Johnson, W.C.; Poiani, K.A. Climate Change Effects on Prairie Pothole Wetlands: Findings from a Twenty-five Year Numerical Modeling Project. Wetlands 2016, 36, 273-285. [CrossRef]

37. LaBaugh, J.; Winter, T.; Swanson, G.; Rosenberry, D.; Nelson, R.; Euliss, N. Changes in atmospheric circulation patterns affect midcontinent wetlands sensitive to climate. Limnol. Oceanogr. 1996, 41, 864-870. [CrossRef]

38. Vanderhoof, M.K.; Alexander, L.C. The Role of Lake Expansion in Altering the Wetland Landscape of the Prairie Pothole Region, United States. Wetlands 2016, 36, 309-321. [CrossRef]

39. Van der Kamp, G.; Hayashi, M. Groundwater-wetland ecosystem interaction in the semiarid glaciated plains of North America. Hydrogeol. J. 2009, 17, 203-214. [CrossRef]

40. Euliss, N.H.; Labaugh, J.W.; Fredrickson, L.H.; Mushet, D.M.; Laubhan, M.R.K.; Swanson, G.A.; Winter, T.C.; Rosenberry, D.O.; Nelson, R.D. The wetland continuum: A conceptual framework for interpreting biological studies. Wetlands 2004, 24, 448-458. [CrossRef]

41. Van der Valk, A.G. Water-level fluctuations in North American prairie wetlands. Hydrobiologia 2005, 539, 171-188. [CrossRef]

42. McLean, K.I.; Mushet, D.M.; Renton, D.A.; Stockwell, C.A. Aquatic-Macroinvertebrate Communities of Prairie-Pothole Wetlands and Lakes Under a Changed Climate. Wetlands 2016, 36, 423-435. [CrossRef]

43. Leibowitz, S.G.; Mushet, D.M.; Newton, W.E. Intermittent Surface Water Connectivity: Fill and Spill Vs. Fill and Merge Dynamics. Wetlands 2016, 36, 323-342. [CrossRef]

44. Anteau, M.J.; Afton, A.D. Amphipod densities and indices of wetland quality across the upper-Midwest, USA. Wetlands 2008, 28, 184-196. [CrossRef]

45. McLean, K.I.; Mushet, D.M.; Stockwell, C.A. From "Duck Factory" to "Fish Factory": Climate Induced Changes in Vertebrate Communities of Prairie Pothole Wetlands and Small Lakes. Wetlands 2016, 36, 407-421. [CrossRef] 
46. Poiani, K.A.; Johnson, W.C. A Spatial Simulation Model of Hydrology and Vegetation Dynamics in Semi-Permanent Prairie Wetlands. Ecol. Appl. 1993, 3, 279-293. [CrossRef] [PubMed]

47. Johnson, W.C.; Millett, B.V.; Gilmanov, T.; Voldseth, R.A.; Guntenspergen, G.R.; Naugle, D.E. Vulnerability of northern prairie wetlands to climate change. Bioscience 2005, 55, 863-872. [CrossRef]

48. Johnson, W.C.; Werner, B.; Guntenspergen, G.R.; Voldseth, R.A.; Millett, B.; Naugle, D.E.; Tulbure, M.; Carroll, R.W.H.; Tracy, J.; Olawsky, C. Prairie Wetland Complexes as Landscape Functional Units in a Changing Climate. Bioscience 2010, 60, 128-140. [CrossRef]

49. McKenna, O.P.; Mushet, D.M.; Scherff, E.J.; McLean, K.I.; Mills, C.T. The Pothole Hydrology-Linked Systems Simulator (PHyLiSS)_Development and Application of a Systems Model for Prairie-Pothole Wetlands; 2018-1165; Geological Survey (USGS): Reston, VA, USA, 2018; p. 34.

50. Samson, F.; Knopf, F. Prairie conservation in North America. Bioscience 1994, 44, 418-421. [CrossRef]

51. Tangen, B.A.; Wiltermuth, M.T. Prairie Pothole Region Wetlands and Subsurface Drainage Systems: Key Factors for Determining Drainage Setback Distances. J. Fish Wildlife Manag. 2018, 9, 274-284. [CrossRef]

52. Van Meter, K.J.; Basu, N.B. Signatures of human impact: Size distributions and spatial organization of wetlands in the Prairie Pothole landscape. Ecol. Appl. 2015, 25, 451-465. [CrossRef]

53. Serran, J.N.; Creed, I.F. New mapping techniques to estimate the preferential loss of small wetlands on prairie landscapes. Hydrol. Process. 2016, 30, 396-409. [CrossRef]

54. Cowardin, L.M.; Shaffer, T.L.; Arnold, P.M. Evaluations of Duck Habitat and Estimation of Duck Population Sizes with a Remote-Sensing-Based System; 2; U.S. Fish and Wildlife Service: Washington, DC, USA, 1995.

55. Krapu, C.; Kumar, M.; Borsuk, M. Identifying Wetland Consolidation Using Remote Sensing in the North Dakota Prairie Pothole Region. Water Resour. Res. 2018, 54, 7478-7494. [CrossRef]

56. Wiltermuth, M.T.; Anteau, M.J. Is consolidation drainage an indirect mechanism for increased abundance of cattail in northern prairie wetlands? Wetlands Ecol. Manag. 2016, 24, 533-544. [CrossRef]

57. Dahl, T.E.; Allord, G.J. History of wetlands in the conterminous United States. In National Water Summary on Wetland Resources; Volume Water Supply Paper 2425; Fretwell, J.D., Williams, J.S., Redman, P.J., Eds.; U.S. Geological Survey: Washington, DC, USA, 1996; p. 439.

58. Oslund, F.T.; Johnson, R.R.; Hertel, D.R. Assessing Wetland Changes in the Prairie Pothole Region of Minnesota From 1980 to 2007. J. Fish Wildlife Manag. 2010, 1, 131-135. [CrossRef]

59. Wright, C.K.; Wimberly, M.C. Recent land use change in the Western Corn Belt threatens grasslands and wetlands. Proc. Natl. Acad. Sci. USA 2013, 110, 4134-4139. [CrossRef] [PubMed]

60. Johnston, C.A. Wetland Losses Due to Row Crop Expansion in the Dakota Prairie Pothole Region. Wetlands 2013, 33, 175-182. [CrossRef]

61. Rashford, B.S.; Bastian, C.T.; Cole, J.G. Agricultural Land-Use Change in Prairie Canada: Implications for Wetland and Waterfowl Habitat Conservation. Can. J. Agric. Econ. 2011, 59, 185-205. [CrossRef]

62. Janke, A.K.; Anteau, M.J.; Stafford, J.D. Prairie wetlands confer consistent migrant refueling conditions across a gradient of agricultural land use intensities. Biol. Conserv. 2019, 229, 99-112. [CrossRef]

63. Van Der Kamp, G.; Stolte, W.J.; Clark, R.G. Drying out of small prairie wetlands after conversion of their catchments from cultivation to permanent brome grass. Hydrol. Sci. J. 1999, 44, 387-397. [CrossRef]

64. McCauley, L.A.; Anteau, M.J.; van der Burg, M.P.; Wiltermuth, M.T. Land use and wetland drainage affect water levels and dynamics of remaining wetlands. Ecosphere 2015, 6, 6. [CrossRef]

65. Gupta, S.C.; Kessler, A.C.; Brown, M.K.; Zvomuya, F. Climate and agricultural land use change impacts on streamflow in the upper midwestern United States. Water Resour. Res. 2015, 51, 5301-5317. [CrossRef]

66. Stewart, R.E.; Kantrud, H.A. Classification of Natural Ponds and Lakes in the Glaciated Prairie Region; 92; US Bureau of Sport Fisheries and Wildlife: Washington, DC, USA, 1971; p. 64.

67. Menne, M.J.; Durre, I.; Vose, R.S.; Gleason, B.E.; Houston, T.G. An Overview of the Global Historical Climatology Network-Daily Database. J. Atmosp. Oceanic Technol. 2012, 29, 897-910. [CrossRef]

68. Wilen, B.O.; Bates, M. The US fish and wildlife service's national wetlands inventory project. In Classification and Inventory of the World's Wetlands; Springer: Berlin/Heidelberg, Germany, 1995; pp. 153-169.

69. Understanding Color - Infrared Photographs; 129-01; Geological Survey (USGS): Reston, VA, USA, 2001.

70. Lishawa, S.C.; Treering, D.J.; Vail, L.M.; McKenna, O.; Grimm, E.C.; Tuchman, N.C. Reconstructing plant invasions using historical aerial imagery and pollen core analysis: Typha in the Laurentian Great Lakes. Divers. Distrib. 2013, 19, 14-28. [CrossRef] 
71. McCauley, L.A.; Anteau, M.J. Generating Nested Wetland Catchments with Readily-Available Digital Elevation Data May Improve Evaluations of Land-Use Change on Wetlands. Wetlands 2014, 34, 1123-1132. [CrossRef]

72. Liu, Y.; Yang, W.; Shao, H.; Yu, Z.; Lindsay, J. Development of an Integrated Modelling System for Evaluating Water Quantity and Quality Effects of Individual Wetlands in an Agricultural Watershed. Water 2018, 10, 774. [CrossRef]

73. Vanderhoof, M.K.; Distler, H.E.; Lang, M.W.; Alexander, L.C. The influence of data characteristics on detecting wetland/stream surface-water connections in the Delmarva Peninsula, Maryland and Delaware. Wetlands Ecol. Manag. 2018, 26, 63-86. [CrossRef]

74. USGS. 1/9th Arc-second Digital Elevation Models (DEMs)_USGS National Map 3DEP Downloadable Data Collection; U.S. Geological Survey: Washington, DC, USA, 2017.

75. Cronshey, R.; McCuen, R.; Miller, N.; Rawls, W.J.; Robbins, S.; Woodward, D. Urban. Hydrology for Small Watersheds; United States Department of Agriculture: Washington, DC, USA, 1986.

76. Palmer, W.C. Meteorological Drought; US Weather Bureau: Washington, DC, USA, 1965; p. 58.

77. Hamon, W.R. Estimating potential evapotranspiration. J. Hydraulics Div. 1961, 87, 107-120.

78. Huang, S.; Young, C.; Abdul-Aziz, O.I.; Dahal, D.; Feng, M.; Liu, S. Simulating the water budget of a Prairie Potholes complex from LiDAR and hydrological models in North Dakota, USA. Hydrol. Sci. J. 2013, 58, 1434-1444. [CrossRef]

79. Couturier, D.; Ripley, E. Rainfall interception in mixed grass prairie. Can. J. Plant Sci. 1973, 53, $659-663$. [CrossRef]

80. Clark, O.R. Interception of rainfall by prairie grasses, weeds, and certain crop plants. Ecol. Monographs 1940, 10, 243-277. [CrossRef]

81. Gleason, R.A.; Laubhan, M.K.; Euliss, N.H., Jr. Ecosystem Services Derived from Wetland Conservation Practices in the United States Prairie Pothole Region with an Emphasis on the U.S. Department of Agriculture Conservation Reserve and Wetlands Reserve Programs; 1745; US Geological Survey: Reston, VA, USA, 2008.

82. Haque, A.; Ali, G.; Badiou, P. Hydrological dynamics of prairie pothole wetlands: Dominant processes and landscape controls under contrasted conditions. Hydrol. Process. 2018, 32, 2405-2422. [CrossRef]

83. McIntyre, N.E.; Liu, G.; Gorzo, J.; Wright, C.K.; Guntenspergen, G.R.; Schwartz, F. Simulating the effects of climate variability on waterbodies and wetland-dependent birds in the Prairie Pothole Region. Ecosphere 2019, 10, e02711. [CrossRef]

84. Steen, V.; Sofaer, H.R.; Skagen, S.K.; Ray, A.J.; Noon, B.R. Projecting species' vulnerability to climate change: Which uncertainty sources matter most and extrapolate best? Ecol. Evol. 2017, 7, 8841-8851. [CrossRef]

85. Liu, G.; Schwartz, F.W. An integrated observational and model-based analysis of the hydrologic response of prairie pothole systems to variability in climate. Water Resour. Res. 2011, 47, 2. [CrossRef]

86. Liu, G.; Schwartz, F.W.; Wright, C.K.; McIntyre, N.E. Characterizing the Climate-Driven Collapses and Expansions of Wetland Habitats with a Fully Integrated Surface-Subsurface Hydrologic Model. Wetlands 2016, 36, 287-297. [CrossRef]

87. McIntyre, N.E.; Wright, C.K.; Swain, S.; Hayhoe, K.; Liu, G.; Schwartz, F.W.; Henebry, G.M. Climate forcing of wetland landscape connectivity in the Great Plains. Front. Ecol. Environ. 2014, 12, 59-64. [CrossRef]

88. Ouyang, Z.; Becker, R.; Shaver, W.; Chen, J. Evaluating the sensitivity of wetlands to climate change with remote sensing techniques. Hydrol. Process. 2014, 28, 1703-1712. [CrossRef]

(C) 2019 by the authors. Licensee MDPI, Basel, Switzerland. This article is an open access article distributed under the terms and conditions of the Creative Commons Attribution (CC BY) license (http://creativecommons.org/licenses/by/4.0/). 